\title{
The application of circular polarized light in soil micromorphology
}

\author{
Th. Pape
}

Soil Science Department, State Agricultural University, Wageningen, the Netherlands

Accepted: 16 November 1973

\begin{abstract}
Summary
Circular polarization can be used on most polarization microscopes with rather cheap accessories. Application in soil micromorphology results in elimination of all extinction phenomena of anisotropic compounds in thin sections. This effect has advantages for direct observations, for quantitative analyses and for microphotographic purposes. Especially when a large microscope stage is used, which makes it impossible to turn the table or the crossed polarizers, the method is very valuable.
\end{abstract}

\section{Introduction}

Various techniques are used in microscopical investigations of soil thin sections. Most common is the use of transmitted light for the more or less transparent soil components or reflected light for the recognition of opaque minerals and some crystalline compounds. With transmitted light one can use ordinary light (without polarizers) or plane polarized light (with only one polarizer) to separate transparent and opaque material. With both polarizers in crossed position anisotropic soil components can be identified. Other microscopical techniques currently being used include phase contrast (Altemüller, 1964), interference (Altemüller, pers. comm., 1972) and fluorescence (Babel, 1972.

In combination with crossed polarizers various accessories may be used, such as dark-field illumination, colour filters and different types of compensators such as gypsum, mica and quarz plates (Guardiola-Saenz \& Delgado-Rodriguez, 1969). Wellknown in mineralogical investigations, but relatively unknown in soil micromorphology is the use of circular polarization (Mücher, 1973). Rosenbusch (1907-1927) already mentions the method in 1927. Freund (1957) and Wahlstrom (1960) give a clear explanation of the behaviour of light waves in diferent types of polarized light and its effect in a microscopical preparation. Geyger (1964) and Geyger \& Beckmann (1967) apply the method to obtain a better contrast between pores and mineral components on soil microphotographs used for quantitative analyses. This paper describes the method and gives some applications in soil micromorphology.

\section{Method}

In our department circular polarization is used on a Leitz polarization microscope (Ortholux or Dialux). For the study of large thin sections $(10 \times 20 \mathrm{~cm})$ (Jongerius \& 

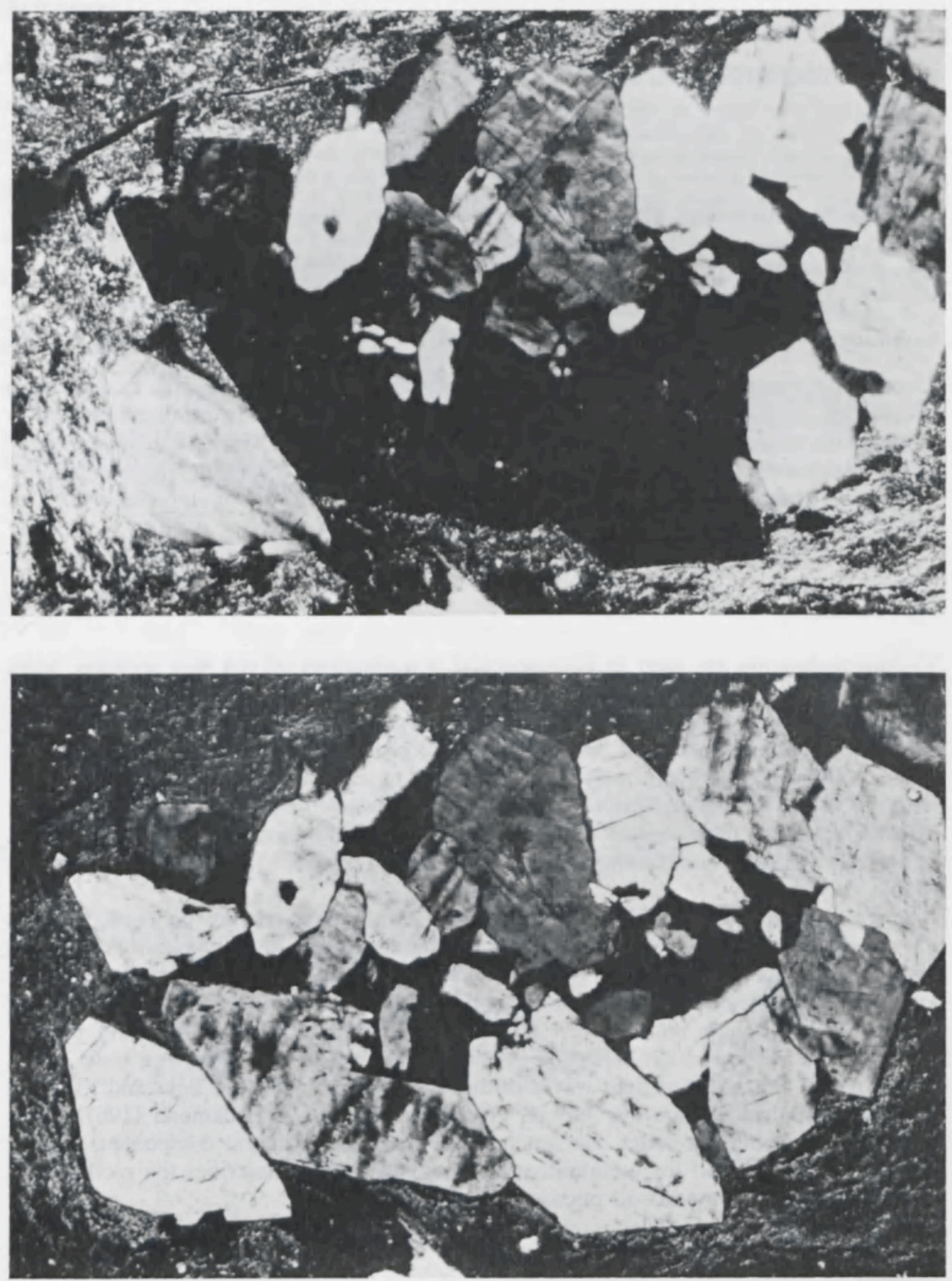

Fig. 1. Concentration of gypsum crystals in a marine deposit from Thailand.

Top: with crossed polarizers part of the crystals is in extinction.

Bottom: with circular polarization all the crystals are illuminated and thus visible. Magnification $\times 39$. 

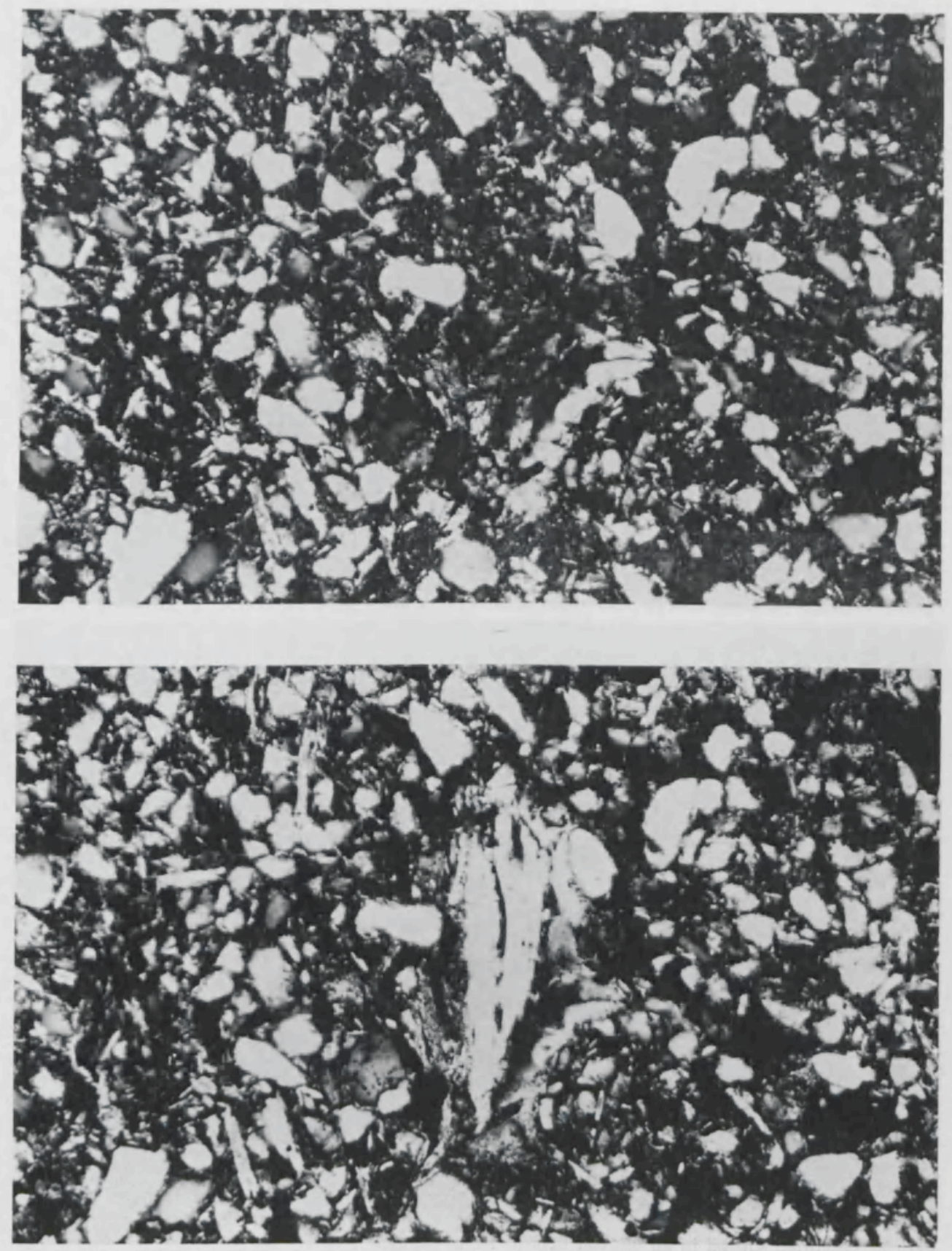

Fig. 2. Detail of an argillic horizon in a loess deposit from the Netherlands.

Top: with crossed polarizers only a part of the papule (remnant of a clay illuviation cutan) is visible due to extinction phenomena.

Bottom: with circular polarization the whole feature is visible.

Magnification $\times 153$. 

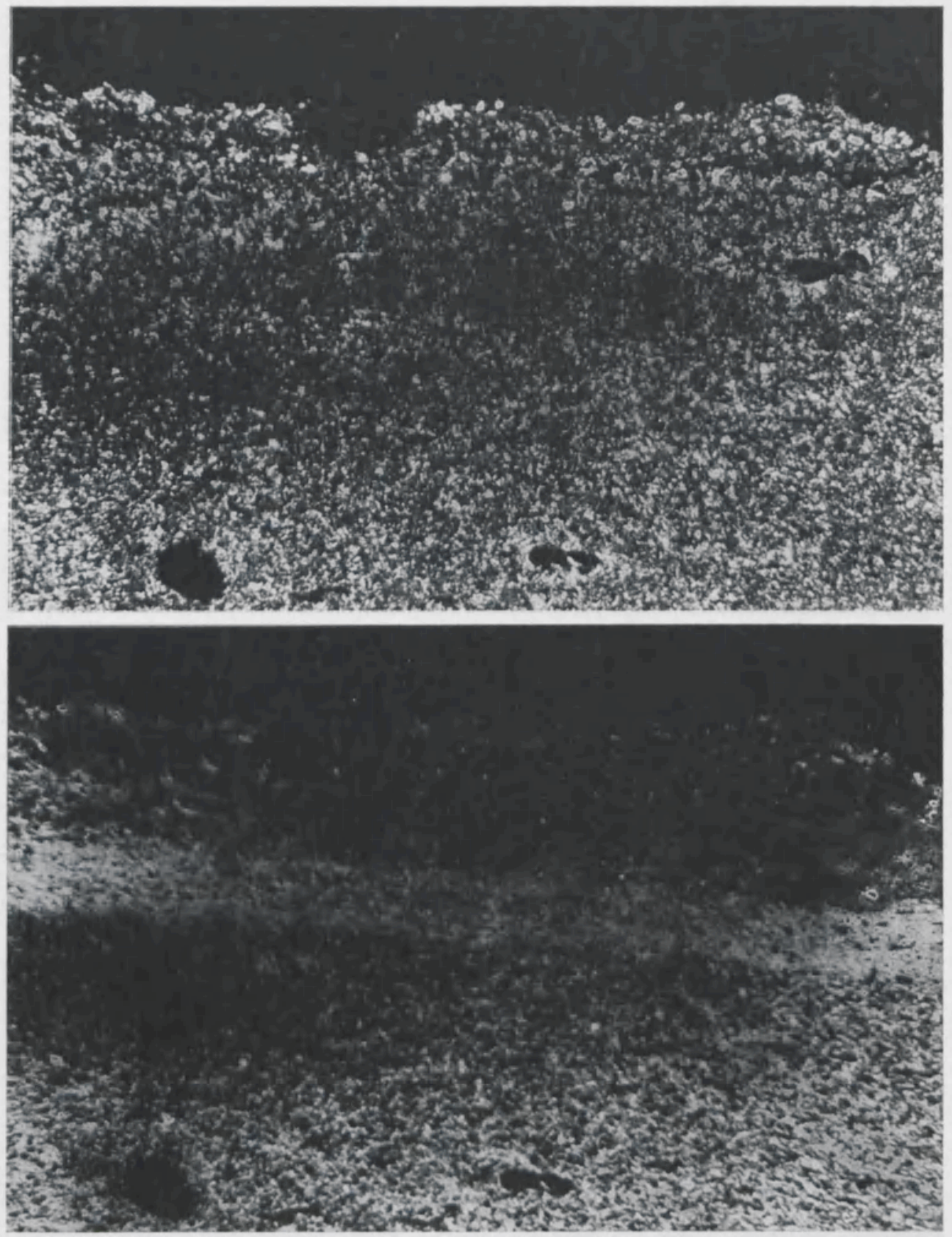

Fig. 3. Stratified subsoil in an alluvial deposit from Thailand.

Top: with crossed polarizers neither the orientation of the clay plasma in mainly one direction nor the stratification is visible.

Bottom: with circular polarization both the unistrial fabric of the clay plasma and the stratification are visible.

Magnification $\times 39$. 
Heintzberger, 1963) the Ortholux microscopes are equiped with a non-turnable, rightangled stage of about $25 \times 35 \mathrm{~cm}$. Two mica plates of $1 / 4 \lambda$ are inserted between polarizer and object and between object and analyser in a crossed position. Polarizer and analyser are in a crossed position too. The two crosses are mutually oriented under an angle of $45^{\circ}$. In this way the light is still polarized, and thus vibrating in a plane, but it describes a circle if projected in a plane perpendicular to the direction of propagation. Its effect in thin sections is that all extinction phenomena of anisotropic materials disappear. They show birefringence independant of their position and orientation. Only isotropic minerals and those which are seen exactly along their optical axis appear dark.

\section{Application}

The method has some advantages in comparison with other methods. One can eliminate extinction phenomena by turning the microscope stage, but this is impossible in case of the above-mentioned large stage. Morover it is impossible to make microphotographs in this way. Another method is to turn the crossed polarizers simultaneously, but this is very difficult to realize with the large stage in such a way that entirely sharp microphotographs are produced. Circular polarization makes both methods superfluous.

A number of features derived from soil forming processes are mainly recognized by the birefringence of the single particles, or by the birefringence caused by the orientation of the composing particles. In many cases they become clearer in circular polarization, particularly when they are small in size, number or area. To the first group belong skeleton grains, plasma and crystallaria (Fig. 1) and to the second group illuviation features (Fig. 2), stress phenomena and sedimentary relicts (Fig. 3) (Brewer, 1964). It is likely that certain plasmic fabrics of Brewer (1964) like 'lattisepic' and 'right bimasepic' have arisen from the fact that part of the oriented plasma was in extinction, although in his chapter on 'plasmic fabrics of sedimentary rocks' he discerns these phenomena. Freund (1957) successfully applied the method for the determination and photographic recording of complicated thread patterns.

Especially the reproduction of oriented clay in complex illuviation and stress features on black-and-white photographs can be improved in this way. For quantification the method is also very suitable, especially when the large microscope stage is used together with the $10 \times 20 \mathrm{~cm}$ thin sections. By example, point counting of clay illuviation features (Miedema \& Slager, 1972) is facilitated because cutans and derived papules (Brewer, 1964) are not in extinction and thus easier to recognize.

\section{Acknowledgments}

The author is indebted to Miss E. Geyger for drawing our attention to the possibilities of the method, to Messrs R. Miedema, H. Mücher, L. P. van Reeuwijk and S. Slager for critical reading of the manuscript and to $\mathrm{Mr} \mathrm{Z}$. van Druuten for making the photographs.

\section{References}

Altemüller, H. J., 1964. Die Anwendung des Phasenkontrastverfahrens bei der Untersuchung von Bodendünnschliffen. In: A. Jongerius (Ed.), Soil micromorphology. Elsevier, Amsterdam, pp. 371-390. 
Babel, U., 1972. Fluoreszenzmikroskopie in der Humusmikromorphologie. In: S. Kowalinski (Ed.), Soil micromorphology. Panstwowe Wydawnictwo Naukowe, Warszawa, pp. 111-127.

Brewer, R., 1964. Fabric and mineral analysis of soils. Wiley, New York-London-Sydney.

Freund, H., 1957. Handbuch der Mikroskopie in der Technik, Band I, Teil 1. Umschau Verlag, Frankfurt am Main.

Geyger, E., 1964. Mikromorphometrische Untersuchungen über den Einfluss bestimmter Pflanzengemeinschaften auf die Strukturbildung im Boden (1). In: A. Jongerius (Ed.), Soil micromorphology. Elsevier, Amsterdam, pp. 445-457.

Geyger, E. \& W. Beckmann, 1967. Apparate und Methoden der mikromorphometrischen Strukturanalyse des Bodens. In: W. L. Kubiena (Ed.), Die mikromorp'zometrische Bodenanalyse. Ferd. Enke, Stuttgart.

Guardiola-Saenz, J. L. \& M. Delgado-Rodriguez, 1969. An accessory plate for the microscopic observation of soils. Soil Sci. 108 (6): 445-447.

Jongerius, A. \& G. Heintzberger, 1963. The preparation of mammoth-sized thin sections. Soil Surv. Pap. 1. Neth. Soil Survey Institute, Wageningen.

Miedema, R. \& S. Slager, 1972. Micromorphological quantification of clay illuviation. J. Soil Sci. 23 (3): $309-314$.

Mücher, H. J., 1973. De micromorfologische analyse van het materiaal. In: P. D. Jungerius, E. A. Koster en F. J. P. M. Kwaad (Ed.), Fysische geografie, aspecten van het landschapsonderzoek. Oosthoek, Utrecht, pp. 77-87.

Parfenova, E. I. \& E. A. Yarilova, 1965. Mineralogical investigations in soil science. Israel Program for Scientific Translations, Jerusalem.

Rosenbusch, H., 1907-1927. Mikroskopische Physiographie der petrografisch wichtigen Mineralien. Stuttgart.

Wahlstrom, E. E., 1960. Optical crystallography, 3rd ed. Wiley, New York-London-Sydney. 